\title{
LIV. On the diffusion of liquids
}

\author{
John H. Long
}

To cite this article: John H. Long (1880) LIV. On the diffusion of liquids, Philosophical Magazine Series 5, 9:58, 413-432, DOI: 10.1080/14786448008626864

To link to this article: http://dx.doi.org/10.1080/14786448008626864

$$
\text { 册 Published online: } 28 \text { Apr } 2009 .
$$

Submit your article to this journal 전

LII Article views: 4

Q View related articles ¿ 
Note.-Silver films might possibly be found useful in the construction of illuminating apparatus for the microscope. If well varnished, they might well replace the usual mercurial reflecting surface used in illuminating-mirrors, as the mercurial layer is very perishable, particularly in a damp climate, as in India during the rainy season.

LIV. On the Diffusion of Liquids.

By JoHN H. Long, of Lawrence, Kansas, U.S.A.

[Concluded from p. 329.]

T $N$ the above I have explained the general workings of the 1 method and discussed its chief sources of error. It remains now to mention several other causes of error. From the tables given it is seen that the amounts diffused undergo slight fluctuations from time to time. Various causes can be assigned for this. The temperature undergoing slight changes has its effect, of course, in producing currents in the solutions, besides changing for the time being their rates of diffusion. Other disturbing currents are produced when, by any cause, the diffusion-vessels are jarred, as when, for instance, a door in their vicinity is rapidly closed. In order to avoid another source of error, it is to be observed, of course, that the table upon which the vessels stand be horizontal, in order that $g h$ be parallel to $e f$.

I turn now to the experiments relating to the comparison of different salts as to their rates of diffusion-the real object of the investigation. This necessitated the performance of a great number of single experiments; and in order that the results of these be comparable, it was necessary that the conditions be in all cases the same. This end could be attained, of course, by diffusing all the salts, one after the other, from the same tube, observing the above-mentioned points regarding concentration \&c. But to carry the investigation out in this way would require a very long time. The only alternative was to make use of a larger number of diffusion-tubes; and this I did. Twelve tubes and beakers, having as nearly as possible the same dimensions and of the form ropresented in fig. 1, were obtained, and compared by filling them with $2 n \mathrm{NaCl}$ solution and observing the amounts diffused in equal times, the velocity of the water being in all cases 40 cubic centims. Some of these tubes were almost immediately rejected : in one the section of $i$ had been left elliptical instead of circular by the glassblower ; in another the point $b$ was too small and did not allow the water to pass through fast enough ; 
and a third was rejected for still another cause. After a number of trials six were found which gave constant results, and diffused amounts of salt in equal times proportional to 17,18 , $17,17,17,17$. Of course these rates were subject to slight fluctuations; but the averages for any length of time were constant. In searching for the cause of the larger amount diffused from the tube No. 2, it was found that in it $i$ was slightly shorter than in the others. A normal $\mathrm{NaCl}$ solution stood in the six tubes at the height $e f$ when the velocity of the water was 40 cubic centims. The exact dimensions of the tubes are as follows-the internal diameter of arst 1.5 millim., the diameter at $b 1$ millım., the diameter of $i 14.5$ millims., the distance $g e 11$ millims., and the distance $g k 15$ millims. The beaker-glasses, when filled to the level $a b$, contained 240 cubic centims. All the experiments described below were performed with these six tubes, and those with the coloured solutions above also. The other experiments cited above were performed with other tubes having slightly different dimensions. In these the part $i$ had a slightly greater diameter (about 16 millims.) and was somewhat shorter.

At the beginning of the series of experiments given below each tube was filled with a different salt-solution; but this plan was soon abandoned, and two salts were then diffused simultaneously-that is, in three of the glasses a solution of one salt, and in the other three a solution of the other. In some cases the amounts diffused from each of the three glasses of each set were determined separately; and in other cases (with the nitrates and sulphates always) the amounts from the three tubes of each set were determined together. The values given below are in all cases the averages reduced for one cell.

The amount given by tube No. 2 was first reduced to the standard of the other five.

The velocity of the water was maintained constant at 40 cubic centims.; and the temperature of the room was $14^{\circ}-16^{\circ} \mathrm{C}$. As explained above, after filling the tubes, about 48 hours were allowed to elapse before the determinations of the diffused salt were commenced. The appearance of the diffusion-cells as they stood when in operation is shown in fig. 3 (Pl. VII.).

The Mariotte bottles held in some cases 8 litres, and in others 4 . The latter are here represented.

The salts made use of were in most cases obtained quite pure ; in other cases it was necessary to purify them myself ( $\mathrm{LiCl}, \mathrm{LiNO}_{3}$ for instance). Where possible, the solutions were made by weighing out the required number of grammes of dry or well-crystallized salt and dissolving this in a litre of water. The strength of this solution was then afterwards 
determined as a control. In the case of some few salts $\left(\mathrm{CaCl}_{2}\right.$ for instance) only the latter method could be well applied.

The first experiments were on solutions of the chlorides; and the diffused amounts were determined by means of $\frac{n}{40} \mathrm{AgNO}_{3}$ with $\mathrm{K}_{2} \mathrm{CrO}_{4}$ as indicator. The burettes were furnished with Erdmann's floats, and their accuracy tested by comparing them with a standard.

The results of the experiments are as follows:-

Diffusion of $2 n \mathrm{NaCl}$.

\begin{tabular}{lrc} 
& \multicolumn{2}{c}{ Cub. cent. } \\
Time. & $n$ & Cub. cent. \\
& $\overline{4} \mathrm{AgNO}_{3} \cdot$ & per hour. \\
$8-9$ & $2 \cdot 1$ & $2 \cdot 10$ \\
$9-11$ & $4 \cdot 0$ & $2 \cdot 00$ \\
$11-2$ & $5 \cdot 7$ & $1 \cdot 90$ \\
$2-4$ & $3 \cdot 7$ & $1 \cdot 85$ \\
$4-8$ A.M. & $28 \cdot 8$ & $1 \cdot 80$ \\
$8-9$ & $2 \cdot 0$ & $2 \cdot 00$ \\
$9-2$ & $10 \cdot 1$ & $2 \cdot 02$ \\
$2-4$ & $4 \cdot 2$ & $2 \cdot 10$ \\
$4-8$ A.M. & $33 \cdot 6$ & $2 \cdot 10$ \\
$8-9$ & $2 \cdot 1$ & $2 \cdot 10$ \\
$9-1$ & $8 \cdot 4$ & $2 \cdot 10$ \\
\hline 53 h. & $104 \cdot 7$ & $1 \cdot 97$
\end{tabular}

Diffusion of $2 n \mathrm{NH}_{4} \mathrm{Cl}$. Cub. cent. Cub. cent.
Time. $\quad \frac{n}{40} \mathrm{AgNO}_{3}$. per hour. 4-8 А.M. $\quad 32 \cdot 5 \quad 2 \cdot 03$ $\begin{array}{lll}8-9 & 2 \cdot 4 & 2 \cdot 40\end{array}$ $\begin{array}{lll}9-10 & 2 \cdot 3 & 2 \cdot 30\end{array}$ $\begin{array}{lll}10-11 & 2 \cdot 4 & 2 \cdot 40\end{array}$ $\begin{array}{lll}11-2 & 7 \cdot 2 & 2 \cdot 40\end{array}$ $2-4 \quad 4.9 \quad 2 \cdot 45$ 4-8 A.M. $\quad 38 \cdot 4 \quad 2 \cdot 40$ $\begin{array}{lll}8-1 & 10 \cdot 5 & 2 \cdot 10\end{array}$ $\begin{array}{lll}45 \mathrm{~h} . & 100 \cdot 6 & 2 \cdot 23\end{array}$

In another experiment with $\mathrm{NH}_{4} \mathrm{Cl}$ solution, 44.5 cubic centims. were required in 19 hours-that is, $2 \cdot 34$ cubic centims. per hour. The average of these is 2.28 cubic centims. per hour ; and this for $n$ solution is equivalent to about 1.15 cubic centim. per hour, or

$$
0.0369 \text { gram } \mathrm{NH}_{4} \mathrm{Cl} \text { in } 24 \text { hours. }
$$

The rate of the $\mathrm{NaCl}$ solution is almost exactly equivalent to 1 cubic centim. per hour for $n$ solution, or

$$
0.0351 \text { gram } \mathrm{NaCl} \text { in } 24 \text { hours. }
$$

Diffusion of $n \mathrm{KCl}$.

\begin{tabular}{|c|c|c|}
\hline Time. & $\frac{n}{40} \mathrm{AgNO}_{3}$. & $\begin{array}{l}\text { Cub. cent. } \\
\text { per hour. }\end{array}$ \\
\hline $8-9$ & $1 \cdot 40$ & $1 \cdot 40$ \\
\hline $9-11$ & 2.90 & $1 \cdot 45$ \\
\hline $11-2$ & $4 \cdot 35$ & $1 \cdot 45$ \\
\hline $2-4$ & $2 \cdot 64$ & $1 \cdot 32$ \\
\hline 4-8 А.м. & $20 \cdot 85$ & $1 \cdot 30$ \\
\hline $8-10$ & $2 \cdot 70$ & $1 \cdot 35$ \\
\hline 6 & 4.84 & $1 \cdot 34$ \\
\hline
\end{tabular}
Cub. cent.
Diffusion of $2 n$ LiCl. Cub. cent. Cub. cent. Time. $\quad \frac{n}{40} \mathrm{AgNO}_{3}$. $\begin{aligned} & \text { Cub, cent. } \\ & \text { per hour. }\end{aligned}$

\begin{tabular}{lrr}
$3-4$ & $2 \cdot 1$ & $2 \cdot 10$ \\
$4-8$ A.M. & $28 \cdot 8$ & $1 \cdot 80$ \\
$8-11$ & $5 \cdot 1$ & $1 \cdot 70$ \\
$11-2$ & $5 \cdot 7$ & $1 \cdot 90$ \\
$2-4$ & $3 \cdot 8$ & $1 \cdot 90$ \\
$4-8$ A.M. & $30 \cdot 4$ & $1 \cdot 90$ \\
\hline 41 h. & $75 \cdot 9$ & $1 \cdot 85$
\end{tabular}


This is equivalent to

0.0599 gram $\mathrm{KCl}$ in 24 hours;

and for $u \mathrm{LiCl} 0.93$ eubic centim. per hour, or

$0.0237 \mathrm{gram} \mathrm{LiCl}$ in 24 hours.

Another series of experiments gave

0.0230 gram $\mathrm{LiCl}$ in 24 hours.

The $\mathrm{LiCl}$ was not absolutely free from $\mathrm{NaCl}$, although treated a number of times with alcohol in the ustal manner. The spectroscope still showed the yellow line. Other metals were absent.

\begin{tabular}{|c|c|c|c|c|c|}
\hline \multicolumn{3}{|c|}{ Diffusion of $n \mathrm{CaCl}_{2}$. } & \multicolumn{3}{|c|}{ Diffusion of $n \mathrm{MgCl}_{2}$. } \\
\hline Time. & $\begin{array}{l}\text { Cub. cent. } \\
\frac{n}{40} \mathrm{AgNO}_{3} .\end{array}$ & $\begin{array}{l}\text { Cub. cent. } \\
\text { per hour. }\end{array}$ & Time. & $\begin{array}{l}\text { Cub. cent. } \\
\frac{n}{40} \mathrm{AgNO}_{3} \text {. }\end{array}$ & $\begin{array}{l}\text { Cub. cent. } \\
\text { per hour. }\end{array}$ \\
\hline $9-12$ & $3 \cdot 9$ & $1 \cdot 30$ & $11-1$ & $2 \cdot 8$ & $1 \cdot 40$ \\
\hline $12-3$ & $3 \cdot 9$ & $1 \cdot 30$ & $1-3$ & $3 \cdot 3$ & $1 \cdot 65$ \\
\hline $3-5$ & $2 \cdot 7$ & $1: 35$ & $3-5$ & $2 \cdot 9$ & $1 \cdot 45$ \\
\hline 5-9 А.м. & $24 \cdot 0$ & 1.50 & 5-9 А.м. & $20 \cdot 8$ & $1 \cdot 30$ \\
\hline $9-10$ & $1 \cdot 3$ & $1 \cdot 30$ & $9-5$ & $8 \cdot 8$ & $1 \cdot 10$ \\
\hline $25 \mathrm{~h}$. & $35 \cdot 8$ & $1 \cdot 43$ & $30 \mathrm{~h}$. & $38 \cdot 6$ & $1 \cdot 29$ \\
\hline
\end{tabular}

The first of these corresponds to

$$
0.0476 \text { gram } \mathrm{CaCl}_{2} \text { in } 24 \text { hours. }
$$

In another series of experiments with $\mathrm{MgCl}_{2}, 21 \cdot 6$ cubic centims. were required in 16 hours. The average of these corresponds to

0.0373 gram $\mathrm{MgCl}_{2}$ in 24 hours.

Diffusion of $\frac{n}{2} \mathrm{BaCl}_{2}$.

$\begin{array}{ll}\text { Cub. cent. } & \text { Cub. cent. } \\ \text { Time. } & \frac{n}{40} \mathrm{AgNO}_{3} \text {. per hour. }\end{array}$

4-8 A.M. $11 \cdot 40 \quad 0.71$

$8-9 \quad 0 \cdot 65 \quad 0.65$

$9-11$

$11-2$

$2-4$

$1 \cdot 50$

$0 \cdot 75$

$2 \cdot 40$

$1 \cdot 60$

4-8 A.M. $12 \cdot 30$

$8-10$

10-12

$44 \mathrm{~h}$.
Diffusion of $\frac{n}{2} \mathrm{SrCl}_{2}$.

Cub. cent. Cub. cent. Time. $\frac{n}{40} \mathrm{AgNO}_{3}$. per hour.

$\begin{array}{lll}10-11 & 0.8 & 0.80\end{array}$ $\begin{array}{lll}11-1 & 1 \cdot 7 & 0.85\end{array}$

$1-2 \quad 1 \cdot 0 \quad 1.00$

$\begin{array}{lll}2-4 & 1.5 & 0.75\end{array}$

4-8 A.M. $11.7 \quad 0.73$

$\begin{array}{lll}8-10 & 1.5 & 0.75\end{array}$

10-12 $1 \cdot 4 \quad 0 \cdot 70$

\begin{tabular}{rrr}
$12-7$ & $4 \cdot 6$ & $0 \cdot 67$ \\
\hline $33 \mathrm{h.}$ & $24 \cdot 2$ & 0.73
\end{tabular}


Reduced to normal solutions, these figures correspond to and 0.0936 gram $\mathrm{BaCl}_{2}$ in 24 hours,

0.0686 gram $\mathrm{SrCl}_{2}$ in 24 hours.

Diffusion of $\mathrm{NiCl}_{2}$ and $\mathrm{CoCl}_{2}$.

Experiments with $n$ solutions of these salts required for $\mathrm{CoCl}_{2}, 1.02$ cubic centim. $\frac{n}{40} \mathrm{AgNO}_{3}$ per hour, corresponding to

$0 \cdot 0397$ gram $\mathrm{CoCl}_{2}$ in 24 hours;

and for $\mathrm{NiCl}_{2}, 1.01$ cubic centim. $\frac{n}{40} \mathrm{AgNO}_{3}$ per hour, corresponding to

$$
0.0394 \text { gram } \mathrm{NiCl}_{2} \text { in } 24 \text { hours. }
$$

An attempt was made to determine the rate of diffusion of $\mathrm{Fe}_{2} \mathrm{Cl}_{6}$; but the rapid dissociation of this salt in solution made the results of no value.

\section{Diffusion of Bromides and Todides.}

These salts were diffused as were the chlorides, and determined in the same manner.

Diffusion of $n \mathrm{KBr}$. Oub. cent.

Time. $\quad \frac{n}{40} \mathrm{AgNO}_{3}$. per hour.

\section{$3-5$}

$5-8$ A.

$2 \cdot 74$
$19 \cdot 70$

$6 \cdot 55$

$8-1$

1-5

$5 \cdot 22$

5-8 A.M. $\quad 18.75$

8-12

$12-4$

$6 \cdot 40$

6.04

4-8 А.м. $21 \cdot 64$

8-12

$69 \mathrm{~h}$.
1.37

$1 \cdot 31$

$1 \cdot 31$

$1 \cdot 30$

$1 \cdot 25$

$1 \cdot 60$

1.51

$1 \cdot 35$ $1 \cdot 51$
Diffusion of $n \mathrm{NH}_{4} \mathrm{Br}$.

Time. Cub. cent. Cub. cent. 40 40 $\begin{array}{ccc}8-12 & 4 \cdot 1 & 1.02\end{array}$ $\begin{array}{lll}12-4 & 4 \cdot 0 & 1.00\end{array}$ 4-8 А.м. $\quad 15.6 \quad 0.97$ $\begin{array}{lll}8-12 & 4.5 & 1 \cdot 12\end{array}$ $\begin{array}{lll}12-4 & 4 \cdot 7 & 1 \cdot 17\end{array}$ 4-9 А.м. $18.5 \quad 1.09$ \begin{tabular}{rrr}
$9-1$ & $4 \cdot 5$ & $1 \cdot 12$ \\
\hline $53 \mathrm{~h}$. & $55 \cdot 9$ & $1 \cdot 05$
\end{tabular}

These values correspond to and

0.0965 gram $\mathrm{KBr}$ in 24 hours,

0.0617 gram $\mathrm{NH}_{4} \mathrm{Br}$ in 24 hours.

Experiments with $n$ solutions of $\mathrm{KI}, \mathrm{NaI}, \mathrm{NaBr}$, and $\mathrm{KCy}$ gave the following results :- 
$n \mathrm{KI}$ required 1.37 c.c. $\frac{n}{40} \mathrm{AgNO}_{3}$ per hour $=0.1304 \mathrm{gr}$. KI in 24 hours.

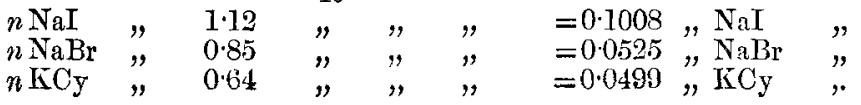

The last value can be considered only an approximation to the truth, as the cyanide contained a little cyanate, and, besides, in solution it suffers always more or less decomposition.

\section{Diffusion of Nitrates.}

The first difficulty in connexion with these salts was the accurate determination of the small amounts diffused. This was finally accomplished, however, by means of the "Marx" method, which, as is well known, depends on the decoloration of a solution of indigo by free $\mathrm{HNO}_{3}$.

An indigo solution was prepared as recommended by Marx*, and was of such strength that 8 cubic centims. corresponded to 1 milligram $\mathrm{NO}_{3}$. The liquid containing diffused salt was evaporated to a small volume and 25 cubic centims. taken. To this were added 50 cubic centims. concentrated $\mathrm{H}_{2} \mathrm{SO}_{4}$, and the indigo was run in immediately from a burette. If more than 30 cubic centims. of this were required, the operation was repeated with a weaker liquid. By means of this preliminary titration it was possible to determine approximately the amount of $\mathrm{NO}_{3}$ in the solution to be examined. This should not contain more than 4 or 5 milligrams in 25 cubic centims. The first test was soon found to be unnecessary, however, as a few titrations showed about how much salt was to be expected for a certain number of hours. Then, by making two titrations, the first a near approximation, it was possible to obtain pretty accurate results. Enough solution was always taken to require from 30 to 50 cubic centims. indigo solution. Observing these precautions, the following experiments were made:-

\begin{tabular}{ll} 
Diffusion of $\frac{n}{4} \mathrm{BaN}_{2} \mathrm{O}_{6}$. \\
Time. & Amount diff. \\
$8-12$ & .0068 gram. \\
$12-6$ & $-0110 \quad$, \\
$6-12$ A.M. & $-0315 \quad "$ \\
$12-6$ & $.0107 \quad "$ \\
$6-12$ A.M. & $.0330 \quad$, \\
\hline 52 hours. & .0930
\end{tabular}

\section{Diffusion of $\frac{n}{4} \mathrm{SrN}_{2} \mathrm{O}_{6}$.}

Time. Amount diff.

6-10 A.M.' 0204 gram. 10-6 $\quad 0090^{\circ}$,

6-12 А.M. -0211, $12-6 \quad 0076$, \begin{tabular}{ccc}
$6-12$ A.M. & $\cdot 0229$, \\
\hline 66 hours. & 0810,
\end{tabular}

* Fresenius' Zeitschrift, vii. p. 412. 
These values correspond to $\left(\frac{n}{4}\right.$ solutions $)$

and

$$
0.0429 \text { gram, } \mathrm{BaN}_{2} \mathrm{O}_{6} \text { in } 24 \text { hours, }
$$

0.0294 gram $\mathrm{SrN}_{2} \mathrm{O}_{6}$ in 24 hours.

Diffusion of $n \mathrm{KNO}_{3}$.

Time.

9-12

$12-3$

3-8 A.M.

$8-4$

4-10 A.M.

10-3

54 hours.
Amount diff.

.0077 gram.

.0071

$\cdot 0450$

$\cdot 0199$

"

,

,

0494

$\cdot 0124$

$\cdot 1415$
Diffusion of $n \mathrm{NH}_{4} \mathrm{NO}_{3}$.

Time. Amount diff.

4-8 A.M. $\quad 0360$ gram.

8-2 0144 "

2-5 0065,

5-9 А.м. 0358 ,

\begin{tabular}{cc}
$9-4$ & $\cdot 0161 \quad \%$ \\
\hline 48 hours. & $\cdot 1088 \quad$,
\end{tabular}

The first corresponds to $\cdot 0026$ gram per hour; another series of experiments gave 0025 gram per hour. The mean of these two corresponds to

0.0614 gram $\mathrm{KNO}_{3}$ in 24 hours.

The second corresponds to 00227 gram $\mathrm{NH}_{4} \mathrm{NO}_{3}$ per hour, or to

0.0544 gram $\mathrm{NH}_{3} \mathrm{NO}_{4}$ in 24 hours.

Normal solutions of $\mathrm{NaNO}_{3}$ and $\mathrm{LiNO}_{3}$ gave quite constant results at the rate of

and

0.0446 gram $\mathrm{NaNO}_{3}$ in 24 hours,

0.0353 gram $\mathrm{LiNO}_{3}$ in 24 hours.

This $\mathrm{LiNO}_{3}$ was prepared from $\mathrm{Mg}$-free $\mathrm{Li}_{2} \mathrm{CO}_{3}$. This was digested a number of times with hot water, and after filtering and drying was found to contain but the merest traces of $\mathrm{Na}_{2} \mathrm{CO}_{3}$, as shown by the spectroscope. The $\mathrm{Li}_{2} \mathrm{CO}_{3}$ was then converted into nitrate.

\section{Diffusion of Sulphates.}

Six different salts of this class, each in $\frac{n}{2}$ solution, were investigated as to their rates of diffusion. An accurate titration of the diffused salt was, of course, impossible in this case ; and weight analyses were resorted to.

At first the liquid obtained in three or four hours from the tubes was evaporated in glass vessels to a small bulk and then 
transferred to a platinum crucible and evaporated to dryness. But this method was soon found to be inconvenient and very inaccurate, as the weight of substance dissolved from the glass vessels during the evaporation was about equal to that of the diffused salt. For a similar reason, it was found unsafe to evaporate in glass and precipitate with $\mathrm{BaCl}_{2}$. These sources of error were finally avoided by evaporating the whole of the liquid obtained in 24 hours in platinum dishes, then precipitating with $\mathrm{BaCl}_{2}$, and weighing as $\mathrm{BaSO}_{4}$. The results of the experiments are as follows, the values being reduced for one cell:-

Diffusion of $\frac{n}{2}\left(\mathrm{NH}_{4}\right)_{2} \mathrm{SO}_{4}$.

1st day diffused $0.0491 \mathrm{gr}$.

2nd " " 0.0492 "

3rd " " $" 0.0463$,

Mean $0.0482 \mathrm{gr} .\left(\mathrm{NH}_{4}\right)_{2} \mathrm{SO}_{4}$ in

24 hours.

Diffusion of $\frac{n}{2} \mathrm{Na}_{2} \mathrm{SO}_{4}$.

1st day diffused $0.0502 \mathrm{gr}$.

2nd ", ", $0 \cdot 0481$,

3rd " " $" \quad 0.0452 "$,

Mean $0.0478 \mathrm{gr} . \mathrm{Na}_{2} \mathrm{SO}_{4}$ in 24 hours.

Diffusion of $\frac{n}{2} \mathrm{ZnSO}_{4}$.

1 st day diffused $0.0298 \mathrm{gr}$.

2nd " " 0.0266 ",

3rd " " $\quad 0.0243 "$

Mean $0.0269 \mathrm{gr} . \mathrm{Zn} \mathrm{SO}_{4}$ in 24

hours.
Diffusion of $\frac{n}{2} \mathrm{CuSO}_{4}$.

1st day diffused $0.0271 \mathrm{gr}$.

2nd " " $" 0.0234$, 3rd " " " $0.0250 "$

Mean $0.0252 \mathrm{gr} . \mathrm{Cu} \mathrm{SO}_{4}$ in 24

hours.

Diffusion of $\frac{n}{2} \mathrm{MgSO}_{4}$.

1st day diffused $0.0243 \mathrm{gr}$.

2nd ", " $" 0.0209$,

3rd " "

4th " " " 0.0183,

Mean $0.0209 \mathrm{gr} . \mathrm{MgSO}_{4}$ in 24

hours.

Diffusion of $\frac{n}{2} \mathrm{MnSO}_{4}$.

1st day diffused $0.0230 \mathrm{gr}$.

2nd ",, 0.0231 ,

3rd " " $\quad 0.0213$,

4th " " $\quad 0.0231$,

Mean $0.0226 \mathrm{gr} . \mathrm{MnSO}_{4}$ in 24

hours.

What are here spoken of as the 1st, 2 nd, and 3rd days are in reality the $3 \mathrm{rd}$, 4th, and 5th days of the experiment, two days being allowed to pass before the determinations were commenced.

Considering all the experiments given above in detail, it will be seen that, as a rule, the progress of the diffusion from day to day was pretty regular, the fluctuations not being greater than one might expect. The sulphates show the greatest irregularities; and it would seem from the results 
found that the two days allowed, in which the diffusion should reach a condition of constancy, was not a period long enough for these salts. It is also possible that this is the normal action of these substances.

But before speaking any further of the probable cause of the above discrepancies, it would be well to compare my results with those of previous experimenters. Of all the results obtained by others only those of Graham can be readily compared. Beilstein neglected to give the dimensions of his diffusion-cell with sufficient accuracy to allow a fair comparison to be made; and Marignac's experiments were conducted in such a way that a direct comparison is impossible. His results can be considered only with reference to each other; and, besides, he has shown that the relative rates of two salts, when simultaneously diffused, are often quite different from their relative rates when diffused alone.

But, fortunately, Graham's work was so performed and his results given in such a form that their reduction and comparison with my own can be more readily made. Graham's diffusion-cells, mentioned at the beginning of this paper, consisted of small phials, $9 \cdot 64$ centims. high, holding 134.8 cubic centims. to the base of the neck. The neck itself was $12 \cdot 7$ millims. high and slightly conical, being on the upper surface 31.49 millims., and on the lower 30.48 millims. in diameter. These phials were filled to the base of the neck with the solution to be examined; and the neck was filled with pure water in such a manner as not to mix the two liquids. The phials were placed in large vessels containing 567 cubic centims. water, and here allowed to remain a number of days. At the end of this time the water was drawn off and the amount of diffused substance analytically determined. The results of these determinations are given in tables, of which the following may serve as a sample. It is from Grabam's second paper on the subject*:-

Diffusion of Chloride of Barium in 8.57 days at $63^{\circ}$ : two cells.

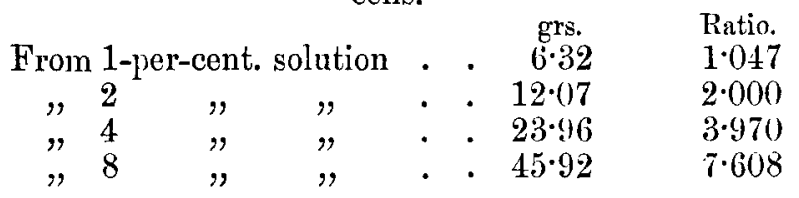

The temperature is given in degrees Fahr. "The quantities $1,2,4$, and 8 per cent. indicate the parts of salt in a con-

* Phil. Trans. 1850, p. 817 . 
stant volume of liquid- $-10,20,40$, and 80 grains of salt in 1000 watergrain measures of the solution." In Graham's tirst paper*, the percentages referred to parts by weight of the solution. These values I have reduced to grams per litre, and the amounts of diffused salt likewise to grams. Then constructing a curve from these data, I have taken out the value corresponding to the amount of salt used per litre in my experiments. For instance, $\mathrm{I}$ used an $n$ solution of $\mathrm{BaCl}_{2}-$ that is, a solution of 104 grams per litre, or, corresponding to the above, a solution of 10.4 per cent. On the curve I have found the amount which should be diffused from a solution of this concentration in the Graham method and compared this with the value found by my own. These amounts depend on the dimensions of the diffusion-vessels ; that is, in the general formula established by Fick,

$$
\frac{q}{l}: \frac{q^{\prime}}{l^{\prime}}:: \mathrm{S}: \mathbf{S}^{\prime}
$$

But $l$ may be taken as equal to $l^{\prime}$, as the distances between the levels of concentration-zero and those of the strong solutions are about the same in both cases. Then

$$
q: q^{\prime}:: \mathrm{S}: \mathrm{S}^{\prime}
$$

or

$$
\mathrm{S}^{\prime}=\frac{\mathrm{S} q^{\prime}}{q}
$$

in which $q$ is the section of the neck of Graham's cells, $q^{\prime}$ a section equal to those of the cells used by me, $\mathrm{S}$ the amount of salt diffused in a given time in a Graham cell, and $\mathbf{S}^{\prime}$ finally the amount which should be diffused in a Graham cell of the same dimensions as those of the cells used by me. This latter is the value sought. $\mathrm{S}, q$, and $q^{\prime}$ are known; and if we consider the lower section of the neck of Graham's cells as determining the amounts diffused, we may write

$$
\mathrm{S}^{\prime}=\frac{\pi 7 \cdot 25^{2}}{\pi 15 \cdot 24^{2}} \mathrm{~S}=0 \cdot 226 \mathrm{~S} \text {. }
$$

If $S$ represents the amount of salt diffused in one day taken as the unit of time, no further reduction is necessary; if not, it simply remains to divide by the number of days of the experiment. This gives, of course, only the mean value for the rate of diffusion during the whole time; but that is the best which can be done under the circumstances.

In this way I have reduced Graham's results; and the values will be found below side by side with my own. No reduction

* Phil. Trans. 1850, p. 1. 
has been made for temperature, as the exact coefficients for this factor are not yet known. Besides, the temperature was nearly the same in all cases of both series of experiments, being with Graham about $60^{\circ}$ to $65^{\circ} \mathrm{F}$., and with me $14^{\circ}$ to $16^{\circ} \mathrm{C}$.

Salt diffused from $n$ solutions in 24 hours.

\begin{tabular}{|c|c|c|c|c|c|}
\hline Formula. & $\begin{array}{c}\text { From my } \\
\text { tubes. }\end{array}$ & $\underset{\text { Groharn's. }}{\text { From }}$ & Formula. & $\begin{array}{c}\text { From my } \\
\text { tubes. }\end{array}$ & $\begin{array}{c}\text { From } \\
\text { Graham's. }\end{array}$ \\
\hline $\mathrm{KCl}$ & gr. & gr. & $\mathrm{NaI}$ & gr. & $\underset{0.0959}{\mathrm{gr} .}$ \\
\hline & .0351 & .0373 & $\mathrm{KCy}$ & $\begin{array}{r}0.0409 \\
.0499\end{array}$ & \\
\hline $\mathrm{NH}_{4} \mathrm{Cl}$ & .0369 & .0378 & $\mathrm{KNO}_{3}$ & .0614 & $\cdot 0715$ \\
\hline Liol ... & .0233 & & $\mathrm{NH}_{4} \mathrm{NO}_{3} \ldots$ & .0544 & $\cdot 0596$ \\
\hline $\begin{array}{l}\mathrm{CaCl}_{2} \ldots \ldots \ldots \\
\mathrm{SrCl}_{2} \ldots \ldots \ldots\end{array}$ & $\begin{array}{l}.0476 \\
.0686\end{array}$ & .0547 & $\begin{array}{l}\mathrm{NaNO}_{3} \\
\text { LiNo }\end{array}$ & $\begin{array}{l}\cdot 0446 \\
\cdot 0353\end{array}$ & $\cdot 0531$ \\
\hline $\mathrm{BaC}$ & $\cdot 0936$ & .0974 & $\mathrm{BaN}_{0} \mathrm{O} \ldots n$ & .0429 & $\cdot 0.096$ \\
\hline & & & & & \\
\hline $\mathrm{MgCl}_{2} \ldots \ldots \ldots$ & $\cdot 0373$ & .0444 & $\mathrm{SrN}_{2} \mathrm{O}_{5} \ldots \frac{n}{4}$ & $\cdot 0294$ & $\cdot 0241$ \\
\hline $\mathrm{CoCl}_{2}$ & 0397 & & $\mathrm{CuSO}_{4} \quad \ldots \frac{n}{2}$ & .0252 & $\cdot 0235$ \\
\hline $\mathrm{NiCl}_{2}$ & .0394 & & $\mathrm{ZnSO}_{\mathrm{k}} \quad \ldots \frac{n}{2}$ & .0260 & .0194 \\
\hline $\mathrm{KBr}$ & $\cdot 0965$ & $\cdot 1037$ & $\mathrm{MnSO}_{4} \ldots \frac{n}{2}$ & .0226 & \\
\hline $\mathrm{NaBr}$ & .0525 & $\cdot 0645$ & $\mathrm{MgSO}_{4} \ldots \frac{n}{2}$ & .0209 & .0150 \\
\hline $\mathrm{NH}_{4} \mathrm{Br}$ & .0617 & & $\mathrm{Na}_{2} \mathrm{SO}_{4} \ldots \frac{n}{2}$ & $\cdot 0478$ & $\cdot 0300$ \\
\hline KI .. & $\cdot 1364$ & $\cdot 1416$ & $(\mathrm{NH})_{2} \mathrm{SO}_{4} \frac{n}{2}$ & $\cdot 0482$ & 0869 \\
\hline
\end{tabular}

It will be seen from the above that the correspondence in the results for the chlorides, bromides, iodides, and some of the nitrates is as close as could reasonably be expected from methods so different as were the two here employed. But the differences in the cases of $\mathrm{BaN}_{2} \mathrm{O}_{6}, \mathrm{SrN}_{2} \mathrm{O}_{6}$, and the five sulphates are far greater than could be allowed for errors of observation or accidental disturbances. Most of Graham's values represent the mean rates of diffusion for periods varying from 5 to 8 days. The values for $\mathrm{BaN}_{2} \mathrm{O}_{6}$ and $\mathrm{SrN}_{2} \mathrm{O}_{6}$, however, are the mean rates for 11.43 days; and those given for $\mathrm{MgSO}_{4}$ and $\mathrm{ZnSO}_{4}$ are the mean rates for the period of $16 \cdot 16$ days. The other sulphates were diffused for 8 days. The discrepancies might be accounted for, in some cases, by assuming that the periods chosen by Graham were too long to admit of a fair comparison. Indeed it would seem from my results obtained with the sulphates, that had they been diffused longer and the mean values taken, they wonld have been equally as small as those found by Graham. It will bo of course recognized that a chief advantage in the method 
employed by me rests in the fact that it allows any variation in the rate of diffusion, as in the above case, to be followed from day to day. For the present I must leave the cause of these variations unexplained.

The question now presents itself, Do the phenomena of diffusion bear any relation to other known physical phenomena? or, in other words, are the relations which molecules of different substances bear to each other as regards diffusion analogous to those depending on other molecular actions? From the Tables given above no simple relation is recognizable ; but if instead of giving the results in grams of substance diffused, they be given in number of molecules diffused, several very interesting relations will appear. Of course we have no means of knowing the absolute number of molecules which undergo a change of place; but it is quite easy to express the relative numbers diffused in any given length of time.

In the Tables above the salt diffused is expressed in grams per 24 hours; now if each one of these values be divided by the molecular weight of the salt, the quotients thus obtained will be proportional to the numbers of molecules diffused from the solutions in question in equal times.

It will be remembered that the solutions submitted to diffusion were normal, half-normal, and quarter-normalthat is, wero made to contain a definite number of molecules per constant volume; and it will be interesting to see how many molecules diffused in equal times from solutions which contained originally the same number. This is presented in the following Table. In order to have these values in the form of whole numbers, the quotients as obtained above have been simply multiplied by $1,000,000$, which of course does not alter their relative values. The results obtained from salts diffused in half- or quarter-normal solution have been multiplied by two or four to make the comparison easier. This is not absolutely accurate, as the amounts diffused are not quite proportional to the concentrations; but the error will not be large.

\begin{tabular}{|c|c|c|c|c|c|c|c|c|}
\hline $\mathrm{Cl}$ & 803 & $\mathrm{CaCl}_{2}$ & ... & 429 & KI & 823 & $\mathrm{SuN} O$ & 552 \\
\hline Cl. & 68 & $\mathrm{MgCl}_{2}$ & & 392 & $\mathrm{NaI}$ & 672 & $\left(\mathrm{NH}_{4}\right)_{2}$ & 24 \\
\hline $\mathrm{ac}$ & 60 & $\mathrm{CoCl}_{2}{ }^{2}$ & & 306 & $\mathbf{N H}_{4} \mathbf{N}$ & 68 & & \\
\hline iCl & 54 & $\mathrm{NiCl}_{2}$ & $\ldots$ & 30 & $\mathrm{KNO}_{3}$ & 607 & $\mathrm{MgSO}_{4}$ & \\
\hline$\ldots$ & 7 & $\mathrm{KBr}^{*}$ & & 81 & $\mathrm{NaNO}_{3}$ & 521 & $b_{4}$ & 32 \\
\hline $\mathrm{rC̆}_{2}$ & 432 & $\mathrm{NH}_{t} \mathrm{Br}$ & $\therefore$ & 629 & $\mathrm{Li}$ & 512 & $\mathrm{CuSO}_{4}$ & $316^{\circ}$ \\
\hline$\ldots$ & 450 & $\mathrm{NaBr}$ & & 509 & $\mathbf{B a}$ & 656 & $\mathrm{MnSO}^{+}$ & \\
\hline
\end{tabular}

This arrangenient of the results shows several very inter- 
esting peculiarities. For instance, the chlorides, bromides, and iodides of the alkali metals form a series in which $\mathrm{NH}_{4}$ stands between $\mathrm{K}$ and $\mathrm{Na}$. $\mathrm{KCl}, \mathrm{KBr}, \mathrm{KI}$, and $\mathrm{KCy}$ have nearly the same rate. The same can be said of the corresponding $\mathrm{NH}_{4}$ and $\mathrm{Na}$ salts as far as investigated.

The chlorides of the dyad metals $\mathrm{Ba}, \mathrm{Sr}, \mathrm{Ca}$, and $\mathrm{Mg}$ are also seen to form a series as to their rates of diffusion. In the case of the alkaline nitrates something similar is seen to exist; but these and other analogies will be better understood when presented in tabular form below (p. 426).

If we compare the results in the above Table with those obtained by Kohlrauseh*, on the electrical conducting-power of liquids, several other interesting relations will be observed. It seems to be true in almost every case that those salts which offer the least resistance to the passage of the galvanic current when in solution are the ones which have the fastest rate of diffusion. These analogies will also be found below.

Another relation will be found when we compare the rates of diffusion with the molecular weights and the molecular volumes of the salts dissolved. In most cases it will be seen that those salts having the greatest molecular volumes diffuse the best. Another very interesting relation will be found when the rates of diffusion of the anhydrous salts are compared with their thermal action on being dissolved. Here it appears that those salts which absorb the greatest amount of heat on going into solution-that is, those upon which the greatest amount of work has been expended and which are, as a conquence, in the finest state of division-are the ones which diffuse the most rapidly.

As these several phenomena have in all probability the sume or similar causes, it will be well to present the several series of constants, molecular volume, electrical conducting-power, heat-absorbing power, and rate of diffusion of the various substances in a single Table. The specific gravities of the salts from which the molecular volumes are computed were taken from F. W. Clarke's collection of Tables $\dagger$, and are the mean values of those there given for the substances in question.

The values for the electrical conductivity are from Kohlrausch's papers $\ddagger$ cited above. They are referred to that of $\mathrm{Hg}$ as unit, and are multiplied by $10^{7}$. The solutions were also normal-that is, similar to those used by me.

The calorimetric values are those of Thomsen, Berthelot and

* Wied. Ann. 1879, Nos. 1 \& 2, pp. 1 \& 145.

+ "Constants of Nature," 'Smithsonian Contributions to Knowledge.' Washington, 1873.

$\ddagger$ Wied. Ann. Band vi. pp. 1 \& 145.

Phil. Mrag. S. 5. Vol. 9. No. 58. June 1880. 
Favre and Valson as in Gmelin-Kraut*, and represent the heat absorbed, expressed in the customary units, when the molecular weight in grams of the salt in question is dissolved in excess of water.

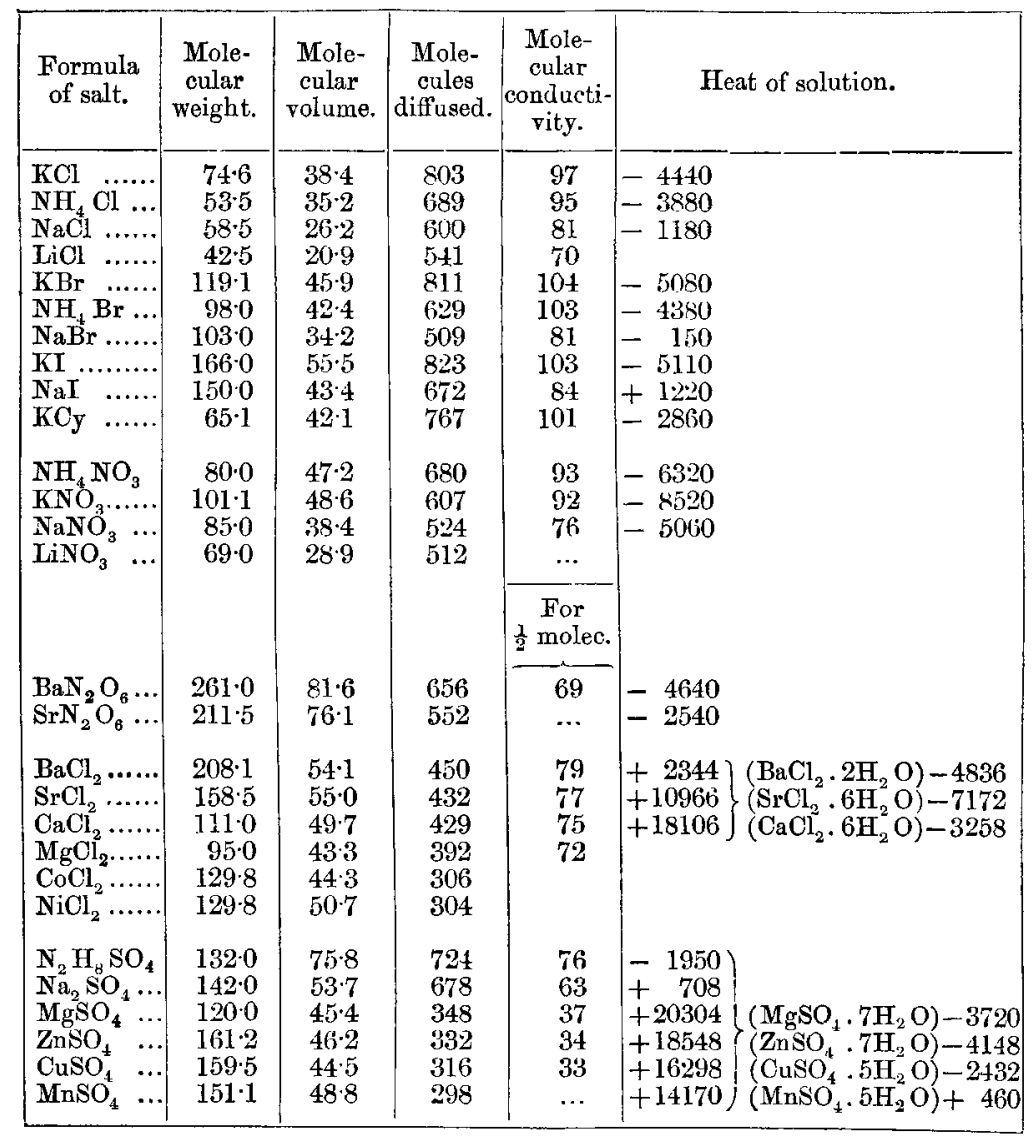

A consideration of the Table shows the completeness of the analogies referred to above. Taking the alkaline chlorides first, it will be seen that they stand in the same order as regards molecular volume, rate of diffusion, conductingpower, and latent heat of solution. Exactly the same is true of the corrosponding bromides and iodides; and the cyanide of potassium has very nearly the same rate of diffusion and electrical conducting-power as the chloride, bromide, and

* Gmelin-Kraut, erster Band, pp. 512-544. 
iodide of the same metal. It is probable that the rate $I$ have found for the bromide of sodium is somewhat too small, being considerably smaller than that found by Graham for the same.

In the next series it is seen that the order of the salts is the same as regards rate of diffusion and electrical conductivity, and the same in respect to molecular volume and latent heat of solution. Ammonium nitrate precedes potassium nitrate in regard to rate of diffusion and conducting-power, and follows it in regard to molecular volume and heat-absorption.

Barium nitrate precedes strontium nitrate in every known respect; to my knowledge, its conducting-power has not yet been determined.

In the series of the dyad chlorides the order is the same in respect to rate of diffusion, conductivity, and latent heat of solution as far as is known. The molecular volume of strontium chloride seems to be slightly greater than that of barium chloride ; but as the values of the specific gravities from which the volumes were calculated differed considerably among themselves, it is possible that the mean taken does not represent the true value.

In the case of the sulphates the order is the same respecting rate of diffusion and electrical conductivity. The sulphates of magnesium, copper, and zinc agree with each other very well in both respects; and it is interesting to observe that the rates of ammonium and sodium sulphates, while also agreeing pretty well in both respects, are much larger than those of the dyad sulphates. The molecular volumes and heats of solution are here quite irregular; indeed the anhydrous sulphates of magnesium, zinc, copper, and manganese stand in exactly reversed orders in respect to their rates of diffusion and latent heats of solution. But a correspondence in this case could hardly be expected, as these substances, on going into solution, combine with large quantities of water and in variable proportions.

It will be seen also from the Table that Graham was scarcely correct in stating that no relation exists between molecular weight and rate of diffusion.

Before seeking for an explanation of these several analogies, it might be well to cite a few more data bearing on the subject. Kohlrausch has shown, in his paper referred to, that the conducting-powers of the acids $\mathrm{HCl}, \mathrm{HBr}, \mathrm{HI}$, and $\mathrm{HNO}_{3}$ are nearly the same. It would be interesting to know how these substances act as regards diffusion. I have not attempted an investigation of thom; but, fortunately, Graham has experimented upon all four ; and his results, reduced to the same standard as above (that is, relative number of mole$2 \mathrm{H} 2$ 
cules diffusod from $n$ solutions in 24 hours), will be found below. The heats of solution for one equivalent of each acid are also given.

\begin{tabular}{|c|c|c|c|c|}
\hline Formula. & $\begin{array}{l}\text { Molecular } \\
\text { weight. }\end{array}$ & $\begin{array}{l}\text { Molecules } \\
\text { diffused. } \\
989\end{array}$ & $\begin{array}{c}\text { Molecular } \\
\text { conductivity. } \\
393\end{array}$ & $\begin{array}{l}\text { Latent heat } \\
\text { of solution. } \\
17500\end{array}$ \\
\hline $\mathrm{HBr}$ & - 81.0 & 965 & 311 & 20000 \\
\hline $\mathrm{HI}$ & . $128 \cdot 0$ & 994 & 328 & 19500 \\
\hline $\mathrm{HNO}_{3}$ & $63 \cdot 0$ & 977 & 334 & 7500 \\
\hline
\end{tabular}

It is seen that the analogy is still preserved; the four acids are as closely related to each other in respect to rate of diffusion as to electrical conductivity. The heats of solution of the three similar acids are also nearly the same; that of $\mathrm{HNO}_{3}$, however, is less.

Of all the above relations, that which seems the most natural and most readily explained is the analogy between rates of diffusion of similarly constituted salts and the amounts of heat they absorb on going into solution. The rendering latent of a large amount of heat indicates the performance of a correspondingly large amount of work. The work in the present case is probably the division of the molecules into smaller aggregates; and these, as is quite plain, are able to move through the solution with greater facility than those which are not so finely divided. Opposed to this, however, we should not expect from a salt having a large molecular volume a rapid rate of diffusion. Now it is possible that the large latent heat corresponds to, and compensates for, the large volume, and the rate of diffusion may not depend upon either. What the true explanation of these facts is I cannot at present say, but must content myself with the mere indication of the several data and their analogies.

On an entirely different footing stand the analogies between rate of diffusion and electrical conducting-power. In both cases a molecular motion is concerned; and although at first sight an explanation may seem as diffreult as before, we have a means of bridging the difficulty. In the first place, it will be well to call to mind the theory of the constitution of solutions as advanced by Clausius* ${ }^{*}$, Williamson $\dagger$, and others. Clausius believes that in a solution of a salt, as $\mathrm{NaCl}$ for instance, the two atoms cannot be assumed as remaining attached closely together, or even as vibrating within limits near each other; but, on the contrary, they fly about in all directions, forming or dissolving connexion with other atoms just according to the

* Pogg. Ann. ci. p. 338.

+ See his "Theory of Etherifications," Chem. Soc. Quart. Journ. iv. p. 229; also Ann. Chem. Pharm. lxxvii. p. 37. 
intensity of the attractions acting upon them at any particular instant of their course. Moreover the velocities with which these two atoms move may be quite different, and what may be spoken of as the velocity of the molecule $\mathrm{NaCl}$ in solution is compounded of the velocities of its two atoms $\mathrm{Na}$ and $\mathrm{Cl}$.

The action of the galvanic current on such a system would then be as follows:- The atoms would still continue to fly about, but in directions more nearly parallel to that of a line joining the two electrodes; and the tendency of these latter to draw to the one side the negative atoms, and to the other the positive, would be facilitated by their continually recurring states of liberty. If a partition be imagined in the vessel in which electrolysis is taking place, say halfway between the two electrodes and perpendicular to the line joining them, it is clear that more positive than negative atoms pass this partition in a positive direction, and more negative than positive atoms pass it in a negative direction in a given time. But positive atoms moving in a negative direction, and negative atoms moving in a positive direction, compensate for each other, and there remains only the excess of motion in each direction; which amounts to saying that a certain number of positive atoms cross the partition in a positive direction, and a certain number of negative atoms cross it in a negative direction, in a given time. "These two numbers need not be the same, as they depend not only upon the impulsive force which for both is the same, but also on the degree of mobility, which for several reasons can be different for different substances"*.

Now the ratio of the number of negative atoms which cross the partition to the number of molecules which may be considered as decomposed in a given time is designated by Hittorf, in his well-known papers on the "Wanderung der Ionen" $\dagger$, with the letter $n$, and called by him the "Ueberführungszall." He shows further that this $n$ is equal to the ratio of the velocity of the negative atoms to the sum of the velocities of both negative and positive atomsł. Kohlrausch, in his papers referred to above, expresses this relation thus,

$$
n=\frac{v}{u+v}
$$

where $v$ is the velocity of the negative and $u$ that of the positive atoms; and from the numerous values of $n$ given by Hittorf for each substance be has deduced those which correspond

* Clausius, loc. cit.

$\dagger$ Pogg. Ann. lxxxix. p. 176 ; xcvii. p. 1 ; ciil. p. 1 ; cvi. p. 337.

$\neq$ See Pogg. Ann. ciii. p. 20, and cri. p. $30 \overline{3}=$ 
to dilute solutions. He has also shown that $v$, the velocity ( $B e-$ weglichkeit, mobility) of a negative atom, as $\mathrm{Cl}$, is the same in all its compounds from which it may be electrolyzed, in $\mathrm{HCl}$, $\mathrm{KCl}, \mathrm{BaCl}_{2}$, and so on. The same is also true for any positive atom, as $\mathrm{K}$ in $\mathrm{KCl}, \mathrm{KOH}, \mathrm{KNO}_{3}$, \&e.

If the values of $n$ for any series of salts as found by Hittorf and reduced by Kohlrausch be compared with the rates of diffusion of the same, it will be found that in the cases where $n$ is large the rate of diffusion is small; and, indeed, in each series the product of $n$ and the latter, which I shall call $d$, is nearly a constant quantity. Considering, for instance, the dyad chlorides, we have

\begin{tabular}{|c|c|c|c|c|c|}
\hline & & & $\frac{n}{2}$ & $d$. & ${ }_{2}^{n} d$ \\
\hline $\mathrm{BaCl}_{2}$ & & & $\cdot 618$ & 450 & 27 \\
\hline $\mathrm{SrCl}_{2}$ & . & . & $\cdot 655$ & 432 & 28 \\
\hline $\mathrm{CaCl}_{2}$ & . & . & $\cdot 673$ & 429 & 2 \\
\hline $\mathrm{MgCl}_{2}$ & . & . & $\cdot 682$ & 392 & 26 \\
\hline
\end{tabular}

In the case of the salts $\mathrm{KCl}, \mathrm{KBr}$, and $\mathrm{KI}$ we have

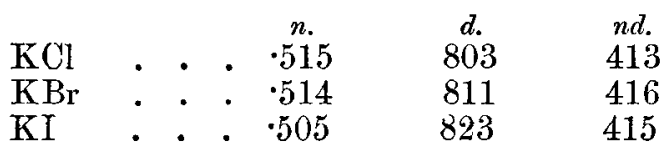

and in the case of the sulphates,

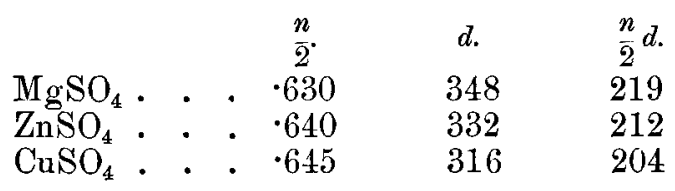

From these tables it appears, comparing any two substances in each series, that

that is,

$$
n: n^{\prime}:: d^{\prime}: d
$$

$$
\frac{v}{v+u}: \frac{v^{\prime}}{v^{\prime}+u^{\prime}}:: d^{\prime}: d
$$

But, as remarked above, $v$ has been shown to be equal to $v^{\prime}$; hence

$$
d: d^{\prime}:: v+u: v+u^{\prime}
$$

that is, the rate of diffusion of a salt is proportional to the sum of the velocities with which its component atoms move during electrolysis.

We shall now be able to understand the analogy between 
my results and those of Kohlrausch; for the latter has shown that the molecular conductivity of a salt in solution depends also on the velocities of its component parts. From this standpoint he has calculated the conducting-powers of the substances for which $n$ is known; and the results thus obtained agree very well with those obtained by experiment.

It appears, then, that the law of the independent migrations of the ions is as applicable before as during the electrolysis of salt in solution; otherwise what is the meaning of the above analogies?

There are also several other phenomena showing a close relation between diffusion and conductivity. Both increase with the temperature, as one might expect; and from Graham's experiments it appears that the increase in the case of diffusion is about the same as Kohlrausch found in the case of conductivity. The influence of temperature on diffusion has been as yet, however, determined but for few substances; and there is of course more or less uncertainty in these determinations.

Another point of analogy is this. Graham has shown that, in the case of nearly every substance investigated by him, the increase in the rate of diffusion is less as the concentration increases. This is also true of the conductivity of the same solutions; and the explanation is the same in both cases. As remarked by Kohlrausch, in concentrated solutions the molecules interfere with each other's motions; and this interference is manifested in the one case by a decrease in the rate of diffusion, and in the other by a decrease in the conductingpower, both relative of course.

Indeed, considering all the above data, it will be seen that the most perfect analogy exists. In the one case the number of particles, in the other the force transmitted by the same is the element observed; and that a correlation should be found is not at all singular.

Whether the velocity of the salt-molecules is the same during diffusion as during electrolysis I cannot say; but it seems to be established by the above that, if any increase take place in the latter case, the fraction representing this increase must be the same for all substances of each series.

But before proceeding any further with this subject, there are several other points which must be investigated. For instance, the rates of diffusion of chlorine and bromine in water must be more exactly determined; and, if possible, more correct determinations of the influence of temperature should be made.

The alkaline hydrates present also a very interesting field 
of investigation; and if the above analogies be general, these bodies must be characterized by a rapid rate of diffusion as well as by good conductivity. There are several phosphates and carbonates which likewise deserve investigation; and these points I expect to make the subject of future examination.

Tübingen, 1879.

\section{Preliminary Notes on Mr. Hall's Recent Discovery. By H. A. RowLand*.}

TTHE recent discovery by Mr. Hall $†$ of a new action of 1 magnetism on electric currents opens a wide field for the mathematician, seeing that we must now regard most of the equations which we have hitherto used in electromagnetism as only approximate, and as applying only to some ideal substance which may or may not exist in nature, but which certainly does not include the ordinary metals. But as the effect is very small, probably it will always be treated as a correction to the ordinary equations.

The facts of the case seem to be as follows, as nearly as they have yet been determined:- Whenever a substance transmitting an electric current is placed in a magnetic field, besides the ordinary electromotive force in the medium, we now have another acting at right angles to the current and to the magnetic lines of force. Whether there may not be also an electromotive force in the direction of the current has not yet been determined with accuracy; but it has been proved, within the limits of accuracy of the experiment, that no electromotive force exists in the direction of the lines of magnetic force. This electromotive force in a given medium is proportional to the strength of the current and to the magnetic intensity, and is reversed when either the primary current or the magnetism is reversed. It has also been lately found that the direction is different in iron from what it is in gold or silver.

To analyze the phenomenon in gold, let us suppose that the line $A B$ represents the original current at the point $A$, and that $\mathrm{BC}$ is the now effect. The magnetic pole is supposed to be either above or below the paper, as the case may be. The line A C will represent the final resultant electromotive force at the point $A$. The circle with arrow represents the direction in which the current is rotated by the magnetism.

* From the American Journal of Mathematics. Communicated by the Physical Society.

† Phil, Mag. [5] vol, ix. p. 225. 